\title{
Lymphogranuloma venereum in Quebec: Re- emergence among men who have sex with men
}

\author{
CA Boutin ${ }^{1}$, S Venne ${ }^{2}$, M Fiset ${ }^{2}$, C Fortin ${ }^{1,3}$, D Murphy ${ }^{3}$, A Severini ${ }^{4}$, C Martineau ${ }^{1,3}$, J Longtin ${ }^{3}$, \\ AC Labbé1,3*
}

\begin{abstract}
Background: Lymphogranuloma venereum (LGV) is a sexually transmitted infection (STI) caused by Chlamydia trachomatis genotypes $L_{1}, L_{2}$ and $L_{3}$. This $L G V$ is associated with significant morbidity and increased risk of HIV transmission. While fewer than two cases per year were reported in Quebec before 2005, LGV emerged in 2005-2006 with 69 cases, followed by a period of low incidence (2007-2012), and subsequent re-emergence since 2013.
\end{abstract}

Objectives: To describe the incidence of LGV in Quebec and the characteristics of the affected population, including demographics and risk factors, clinical manifestations, laboratory tests, treatments and reinfection rates.

Methods: Descriptive data were collected from the notifiable diseases records through the Institut national de santé publique du Québec (INSPQ) infocentre portal. Questionnaires were obtained through the enhanced surveillance system and transmitted anonymously to the Quebec Ministry of Health. In-depth analysis was performed on cases from 2013 to 2016.

Results: There were 338 cases of LGV over the four-year period in Quebec. All cases were male, excluding one transsexual. Mean age was 41 years. Most lived in Montréal (81\%) and were men who have sex with men (MSM; 99\%). The majority (83\%) reported four sexual partners or more in the last year, met mostly through the Internet (77\%) and in saunas (73\%). Frequency of sexual intercourse with out-of-province residents decreased in 2013-2016 (27\%) compared with 2005-2012 (38\%). History of STIs was frequent: 83\% were HIV-infected, $81 \%$ reported previous syphilis and $78 \%$ previous gonorrhea. Recreational drug use was frequent (57\%), reaching $71 \%$ in 2016 . Most cases were symptomatic, a proportion which decreased in 2016 (68\%) compared with 2013-2015 (82\%; $p=0.006)$. Clinical presentations included proctitis $(86 \%)$, lymphadenopathy (13\%) and ulcer/papule (12\%). Reinfections, mostly within two years of first infection, occurred in 35 individuals (10\%).

Conclusion: The re-emergence of LGV in Quebec involves an urban subpopulation composed almost exclusively of MSM with STIs, who have a high number of partners and often use drugs.

\author{
Affiliations \\ 1 Département de microbiologie, \\ infectiologie et immunologie, \\ Université de Montréal, Montréal, \\ $\mathrm{QC}$ \\ ${ }^{2}$ Ministère de la santé et des \\ services sociaux du Québec, \\ Montréal, QC \\ ${ }^{3}$ Institut national de santé \\ publique du Québec, Montréal, \\ $\mathrm{QC}$ \\ ${ }^{4}$ National Microbiology \\ Laboratory, Public Health Agency \\ of Canada, Winnipeg, MB
}

*Correspondence: ac.labbe@ umontreal.ca

Suggested citation: Boutin CA, Venne S, Fiset M, Fortin C, Murphy D, Severini A, Martineau C, Longtin J, Labbé AC. Lymphogranuloma venereum in Quebec: Re-emergence among men who have sex with men. Can Commun Dis Rep. 2018;44(2):55-61. https://doi.org/10.14745/ccdr.v44i02a04

\section{Introduction}

Lymphogranuloma venereum (LGV) is a sexually transmitted infection (STI) caused by Chlamydia trachomatis genotypes $\mathrm{L}_{1}$, $L_{2}$ and $L_{3}\left(L_{1-3}\right)$. It is associated with anogenital fistula, stenosis formation and lymphatic obstruction, among others (1) and increased risk of HIV transmission (1-3). This information was rarely reported in industrialized countries until the early 2000s, but it has since been described in urban settings, mainly among men who have sex with men (MSM). Recent outbreaks occurred in Belgium, France, the Netherlands, the United Kingdom and the United States of America (2). Over the last decade, LGV emerged in Canada, with sporadic outbreaks mainly in major urban centres (3-5).
In Quebec, fewer than two cases per year were reported before a significant rise was noted in 2005 and 2006 with a total of 69 cases. A period of low incidence followed from 2007 to 2012, with a mean of nine cases per year. In 2013, an evolving outbreak started in Montréal.

The classical presentation of LGV is an inguinogenital disease, with an ulcer or papule at the site of inoculation and frequently a unilateral inguinal or femoral lymphadenopathy (1). Many young patients are now presenting with proctitis or proctocolitis, often mimicking the first manifestations of inflammatory bowel disease (2). Prevalence studies have recently found a higher proportion of asymptomatic cases, representing up to $25-27 \%$ of cases in $\operatorname{MSM}(6,7)$. 
In 2014, the Public Health Agency of Canada (PHAC) revised its recommendations to encourage LGV genotyping on positive C. trachomatis specimens among asymptomatic MSM with risk factors, regardless of sampled site; this was further updated in 2017 to focus on rectal specimens only (3). Following expert advice from the Institut national de santé publique du Québec (INSPQ) (8), systematic genotyping of all positive rectal specimens for $C$. trachomatis (regardless of symptomatology) was implemented in June 2016 (the value of this strategy will be assessed after two years). The INSPQ also provides guidelines on treatment of cases and partners (8).

Given the growing epidemic, enhanced surveillance of LGV cases was pursued in Quebec with the goal of implementing targeted public health interventions.

The objective of this article is to describe the Quebec 2013-2016 LGV epidemic and present epidemiologic data including demographic details, risk factors, clinical manifestations, laboratory tests, treatment and reinfection.

\section{Methods}

Until 2005, LGV was part of routine surveillance and notifiable to public health authorities. In 2005, PHAC (9) and the Quebec Ministry of Health initiated an enhanced surveillance system for LGV, whereby when a case is notified, key epidemiologic and clinical information are collected by public health nurses who contact the attending physicians or the patients directly. The nurses administer an epidemiologic questionnaire to collect information about patient demographics (age, sex, area of residence), risk factors (number, sex and meeting context of partners; history of sexually transmitted or blood-borne infections [STBBIs]; drug use), clinical presentation, laboratory tests performed and treatment information. In an attempt to prevent missing any data, epidemiologic questionnaires were revised over the surveillance period and medical teams were contacted, if necessary.

For this present surveillance report, descriptive data for all LGV cases in Quebec from 2013 to 2016 were collected from the notifiable diseases database through the INSPQ infocentre portal and enhanced surveillance questionnaires were transmitted anonymously to the provincial Ministry of Health for compilation and analysis. Surveillance definitions changed over time. In 2013-2014, confirmed cases included:

- Patients with proctitis, inguinal/femoral lymphadenopathy or contact with a confirmed LGV case

- Isolation of C. trachomatis or detection by nucleic acid amplification testing (NAAT) from an appropriate clinical specimen and $\mathrm{L}_{1-3}$ genotype documented through DNA sequencing

In 2015, genotyping alone became sufficient to consider a case confirmed and clinical manifestation or contact with a case were no longer required. Probable cases included patients who presented with proctitis or inguinal/femoral lymphadenopathy or had a contact with a confirmed LGV case and had a positive test for C. trachomatis from an appropriate clinical specimen (10).

Until February 2016, all genotyping was performed at the National Microbiology Laboratory, in Winnipeg, Manitoba. In March 2016, a multiplex polymerase chain reaction (PCR) assay that distinguishes LGV from non-LGV C. trachomatis infections (11) became available at Laboratoire de santé publique du Québec, Sainte-Anne-de-Bellevue, Quebec. Thereafter, only positive LGV samples were sent to the National Microbiology Laboratory for genotype identification by DNA sequencing.

All cases notified in 2013-2016 were investigated to identify any previous episodes since January 1, 2005. A reinfection was defined as a second infection in the same individual occurring at least 90 days after the first episode (12).

Data were analyzed for all 338 cases (or cases for which information was available for a specific variable) notified between 2013 and 2016, excluding one transsexual case (man to woman). Data were analyzed with statistical software Epi Info version 7.2.0.1 and Stata 64 (version 10.1). Proportions were compared using the $x^{2}$ test. The epidemiologic portrait presented here focuses on the 2013-2016 outbreak in Quebec, with parallels to preceding years (i.e. 2005-2012) only where appropriate.

\section{Results}

From January 1, 2013, to December 31, 2016, 338 cases (328 confirmed and 10 probable) were reported: 49 in 2013, 61 in 2014, 105 in 2015 and 123 in 2016 (Figure 1).

Figure 1: Lymphogranuloma venereum among men: annual adjusted rate per 100,000 person years in Quebec, Montréal and outside Montréal, 2005-2016

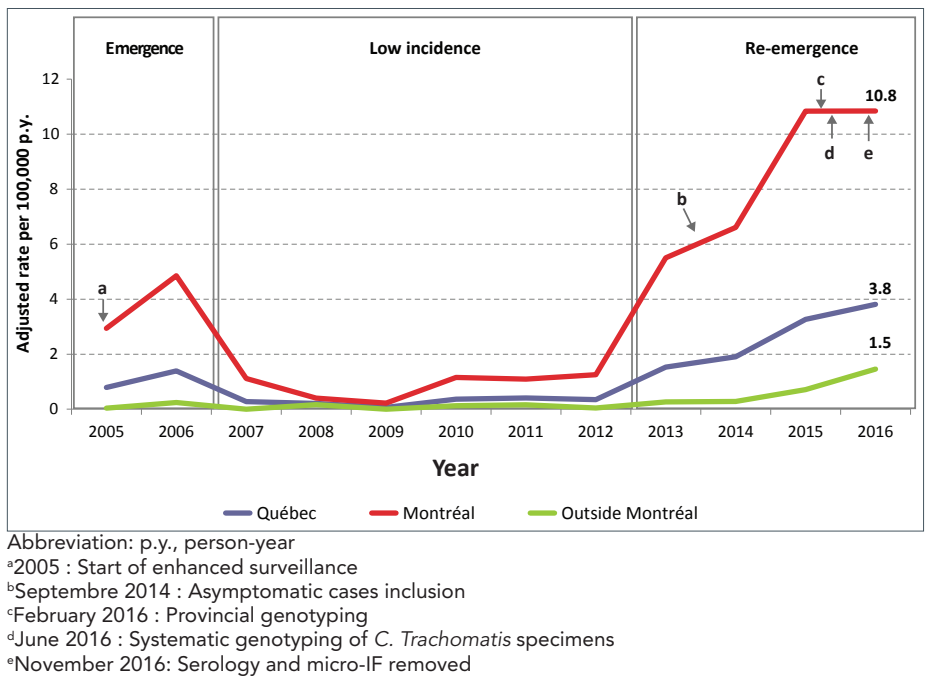

\section{Demographic and risk factors}

The majority of cases were in the 25-54 year age group (83\%) and in Montréal (81\%) (Table 1). Most patients were MSM (99\%), with $3 \%(n=7)$ also having female partners. Half of the patients reported more than 10 sexual partners over the last 12 months $(101 / 205 ; 49 \%)$. Almost all $(96 \%)$ had a new partner and $84 \%$ had anonymous sexual partners. The proportion of cases with more than 20 sexual partners in the last year was higher in Montréal than in the rest of the province $(27 \%$ vs $3 \% ; p<0.001)$. Saunas and Internet (including smartphone networking applications) were two important means of meeting partners. Although not statistically significant $(p=0.07)$, fewer patients $(27 \%)$ had encounters with partners from outside the province in the last year in contrast to preceding years (2005-2012; $n=31 / 81 ; 38 \%)$. Among cases living outside of Montréal, 16/42 (38\%) reported partners from Montréal or out of the province. 
Table 1: Characteristics of male lymphogranuloma venereum cases, Quebec, 2013-2016

\begin{tabular}{|c|c|c|}
\hline \multirow{2}{*}{ Characteristic } & \multicolumn{2}{|c|}{ 2013-2016 } \\
\hline & $n$ & $\%$ \\
\hline \multicolumn{3}{|l|}{ Age $(n=338)$} \\
\hline $15-24$ & 23 & 7 \\
\hline $25-34$ & 98 & 29 \\
\hline $35-44$ & 92 & 27 \\
\hline $45-54$ & 83 & 25 \\
\hline$>55$ & 42 & 12 \\
\hline \multicolumn{3}{|l|}{ Demographics $(n=338)$} \\
\hline Montréal & 273 & 81 \\
\hline Outside of Montréal & 65 & 19 \\
\hline \multicolumn{3}{|l|}{ Sex of partners $(n=287)$} \\
\hline Men only & 279 & 97 \\
\hline Men and women & 7 & 2 \\
\hline Women only & 1 & 0.3 \\
\hline \multicolumn{3}{|l|}{ History of STBBIs ${ }^{b}$} \\
\hline At least one & $286 / 295$ & 97 \\
\hline HIV & $210 / 252$ & 83 \\
\hline Syphilis & $183 / 226$ & 81 \\
\hline Gonorrhea & $165 / 211$ & 78 \\
\hline HBV & $11 / 102$ & 11 \\
\hline $\mathrm{HCV}$ & $11 / 106$ & 10 \\
\hline \multicolumn{3}{|c|}{ Number of partners $(n=205)$ in last 12 months } \\
\hline $1-3$ & 34 & 17 \\
\hline $4-10$ & 70 & 34 \\
\hline $11-20$ & 55 & 27 \\
\hline$>20$ & 46 & 22 \\
\hline \multicolumn{3}{|l|}{ Meeting context ${ }^{\mathrm{b}}$} \\
\hline New partner & $114 / 119$ & 96 \\
\hline Anonymous partners & $82 / 98$ & 84 \\
\hline Sex worker client & $8 / 191$ & 4 \\
\hline Sex worker & $10 / 196$ & 5 \\
\hline Sauna & $136 / 186$ & 73 \\
\hline Internet/Applications & $136 / 177$ & 77 \\
\hline Club/bar & $40 / 115$ & 35 \\
\hline \multicolumn{3}{|l|}{ Drug use $(n=241)$} \\
\hline At least one & 138 & 57 \\
\hline Crystal meth & 50 & 21 \\
\hline Cannabis & 48 & 20 \\
\hline
\end{tabular}

Table 1: Characteristics of male lymphogranuloma venereum cases, Quebec, 2013-2016 (continued)

\begin{tabular}{|c|c|c|}
\hline \multirow{2}{*}{ Characteristic } & \multicolumn{2}{|c|}{$2013-2016$} \\
\hline & $\mathbf{n}$ & $\%$ \\
\hline \multicolumn{3}{|l|}{ Drug use $(n=241)\left(\operatorname{con}^{\prime} t\right)$} \\
\hline Ecstasy & 43 & 18 \\
\hline Cocaine & 28 & 12 \\
\hline Poppers & 27 & 11 \\
\hline Speed & 23 & 10 \\
\hline $\mathrm{GHB}$ & 12 & 5 \\
\hline Ketamine & 10 & 4 \\
\hline Crack & 5 & 2 \\
\hline Heroine & 1 & 0 \\
\hline IV drug & 10 & 4 \\
\hline Not reported & 13 & 5 \\
\hline \multicolumn{3}{|c|}{ Encounter with out-of-province resident $(n=208)$} \\
\hline At least one & 56 & 27 \\
\hline
\end{tabular}

Abbreviations: $\mathrm{GHB}$, gamma-hydroxybutyric acid; $\mathrm{HBV}$, hepatitis $\mathrm{B}$ virus; $\mathrm{HCV}$, hepatitis $\mathrm{C}$ virus; HIV, human immunodeficiency virus; IV, intravenous; n, number; STBBI, sexually transmitted or blood-borne infection

a Repeaters were included twice $(n=35)$

b Proportion for whom information is available differs for each variable

A high proportion of patients $(210 / 252 ; 83 \%)$ were HIV-seropositive (a considerable augmentation from 2005-2012: 48/82; 59\%; $p<0.001)$. Past histories of syphilis $(183 / 226 ; 81 \%)$ and gonococcal $(165 / 211 ; 78 \%)$ infections were also frequently reported. Data on hepatitis $B$ virus (HBV) and hepatitis $\mathrm{C}$ virus (HCV) infection were available for only one-third of cases, of which $11 \%$ and $10 \%$ had a history of past or current infection. The proportion of cases with a history of at least one STBBI was significantly higher in 2013-2016 (286/295; 97\%) than in 2005-2012 (95/112; 85\%; $p<0.001)$.

Information on drug consumption was available for 241/338 cases, of whom $138(57 \%)$ reported drug use during the past year. Crystal meth (21\%), marijuana $(20 \%)$ and ecstasy (18\%) were the most frequently used drugs. A significant rise in crystal meth consumption was observed: $8 \%(3 / 38)$ in 2013, $12 \%(6 / 49)$ in 2014, 25\% (19/77) in 2015 and 29\% (22/76) in 2016 (test for trend, $p=0.008$ ).

\section{Clinical manifestations}

Details about symptoms were available for $303 / 338$ cases. The majority of patients had symptoms at the time of testing $(n=237 ; 78 \%$ ) (Table 2). The proportion of asymptomatic cases increased from 18\% (37/203) in 2013-2015 to $32 \%(32 / 100)$ in $2016(p=0.01)$. A minority of patients presenting with symptoms 
Table 2: Clinical presentation of lymphogranuloma venereum cases, Quebec, 2013-2016

\begin{tabular}{|c|c|c|c|c|c|c|c|}
\hline \multirow[t]{2}{*}{$\begin{array}{l}\text { Clinical } \\
\text { presentation }\end{array}$} & \multicolumn{2}{|c|}{$\begin{array}{c}2013-2016 \\
\text { (Total) } \\
n=303^{a}\end{array}$} & \multicolumn{2}{|c|}{$\begin{array}{c}2013-2015 \\
n=203^{a}\end{array}$} & \multicolumn{2}{|c|}{$\begin{array}{c}2016 \\
n=100^{a}\end{array}$} & \multirow[t]{2}{*}{$\begin{array}{c}P \\
\text { value }\end{array}$} \\
\hline & $\mathrm{n}$ & $\%$ & $\mathrm{n}$ & $\%$ & $\mathbf{n}$ & $\%$ & \\
\hline Asymptomatic & 69 & 23 & 37 & 18 & 32 & 32 & 0.006 \\
\hline $\begin{array}{l}\text { Nonspecific } \\
\text { symptoms }{ }^{b} \text { only }\end{array}$ & 12 & 4 & 6 & 3 & 6 & 6 & NS \\
\hline $\begin{array}{l}\text { Specific } \\
\text { symptom(s)c }\end{array}$ & 222 & 73 & 160 & 79 & 62 & 62 & 0.002 \\
\hline Proctitis & 201 & 66 & 141 & 69 & 60 & 60 & NS \\
\hline Lymphadenopathy & 30 & 10 & 23 & 11 & 7 & 7 & NS \\
\hline Ulcer/papule & 29 & 10 & 25 & 12 & 4 & 4 & NS \\
\hline
\end{tabular}

Abbreviation: NS, not significant; $n$, number

anformation was missing for 35/338 cases (12 in 2013-2015 and 23 in 2016)

b Nonspecific symptoms or signs included malaise/asthenia, urethral discharge, dysuria, arthralgia anal fistula and epidymitis

c Some patients presented with more than one specific symptom $(n=35)$

had only unspecific complaints (12/235; 5\%). As shown in Figure 2, more than one symptom could occur at the same time. Symptoms included proctitis (86\%), ulcer or papule (12\%) and lymphadenopathy (13\%). Complaints associated with proctitis included bloody stools $(69 / 201 ; 35 \%)$, anal pain $(70 / 201 ; 34 \%)$ and rectal discharge $(52 / 201 ; 26 \%)$.

Figure 2: Distribution of clinical manifestations among symptomatic lymphogranuloma venereum cases, Quebec, 2013-2016 $(n=234)^{\mathrm{a}}$

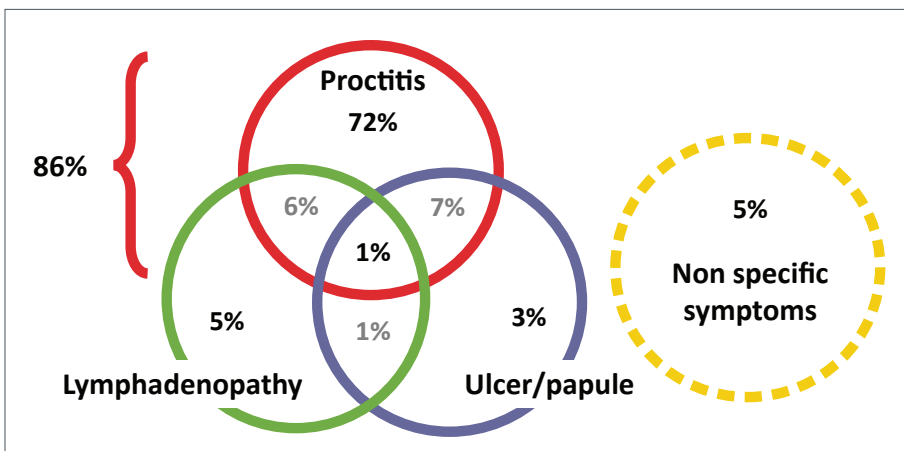

Of 338 lymphogranuloma venereum cases, clinical presentation was known for 303, of which 69 cases were asymptomatic

\section{Laboratory tests and treatment}

The number of LGV genotyping tests performed on positive C. trachomatis samples (males and females, all sampling sites, regardless of symptoms) at the Laboratoire de santé publique du Québec are shown in Table 3. Overall, 13\% of C. trachomatis samples typable by multiplex PCR assay were genotypes $\mathrm{L}_{1-3}$. Some patients had more than one positive sample for a single episode. An important increase in the number of requests was noted in 2016 as a result of the recommendation to systematically genotype all rectal samples positive for C. trachomatis.

The reason for requesting testing was known for 302 of the 338 reported cases. The reasons included presence of symptoms
Table 3: Clinical samples received at the Laboratoire de santé publique du Québec for lymphogranuloma venereum genotyping, 2013-2016

\begin{tabular}{|c|c|c|c|c|c|c|c|}
\hline \multirow[t]{2}{*}{ Year } & \multirow{2}{*}{$\begin{array}{c}\text { C. } \\
\text { trachomatis } \\
\text { positive } \\
\text { samples, } \\
\text { n }\end{array}$} & \multirow{2}{*}{$\begin{array}{l}\text { Typable } \\
\text { by } \\
\text { multiplex } \\
\text { PCR } \\
\text { assay, n }\end{array}$} & \multirow[t]{2}{*}{$\begin{array}{c}\text { Non-LGV } \\
\text { genotypes, } \\
\text { n (\%) }\end{array}$} & \multirow[t]{2}{*}{$\begin{array}{c}\text { LGV } \\
\text { genotypes, } \\
n(\%)\end{array}$} & \multicolumn{3}{|c|}{$\begin{array}{c}\text { Specific } \\
\text { genotype } \\
\text { identified by } \\
\text { sequencing }\end{array}$} \\
\hline & & & & & $\mathrm{L}_{2 b}$ & $\mathrm{~L}_{2}$ & $\mathrm{~N} / \mathrm{A}$ \\
\hline 2013 & 424 & 414 & 363 (88\%) & $51(12 \%)$ & 49 & 2 & 0 \\
\hline 2014 & 540 & 534 & 475 & 59( & 55 & 4 & 0 \\
\hline 2015 & 670 & 656 & $536(82 \%)$ & $120(18 \%)$ & 107 & 4 & 9 \\
\hline 2016 & 1,249 & 1,199 & 1,070 (89\%) & 129 (11\%) & 124 & 0 & 5 \\
\hline Total & 2,883 & 2,803 & 2,444 (87\%) & 359 (13\%) & 335 & 10 & 14 \\
\hline
\end{tabular}

Abbreviations: C. Trachomatis, Chlamydia trachomatis; LGV, lymphogranuloma venereum; PCR, polymerase chain reaction

Includes males and females, from any sampled site

Notes: Some LGV cases were reported on the basis of serology before November 2016. Some patients had more than one positive sample for a single episode

$(n=221 ; 73 \%) ;$ screening based on risk factors $(n=68 ; 23 \%)$; and contact with a confirmed LGV case $(n=12 ; 4 \%)$. DNA sequencing was conducted for $93 \%(n=314)$ of cases: 304 were $L_{2 b}$, whereas 10 typed as $L_{2}$, due to a single nucleotide mutation in the genotyping target of the ompA gene. Retrospective sequencing of the $\mathrm{pmpH}$ gene suggests that these cases were due to a variant of the $L_{2 b}$ genotype.

Prescribed treatment was in line with guidelines (doxycycline for 21 days) $(3,8)$ for $77 \%$ of cases $(221 / 288)$, and appropriate treatment was more often initially prescribed in 2016 than in 2013-2015 (74\% vs 61\%; $p=0.03$ ) (Table 4).

Table 4: Treatment of lymphogranuloma venereum cases, Quebec, 2013-2016

\begin{tabular}{|c|c|c|c|c|c|c|c|}
\hline \multirow[t]{2}{*}{ Treatment } & \multicolumn{2}{|c|}{$\begin{array}{c}2013-2016 \\
\text { (Total) } \\
n=288^{a}\end{array}$} & \multicolumn{2}{|c|}{$\begin{array}{c}2013-2015 \\
n=194^{a}\end{array}$} & \multicolumn{2}{|c|}{$\begin{array}{c}2016 \\
n=94^{a}\end{array}$} & \multirow[t]{2}{*}{$p$ value } \\
\hline & $n$ & $\%$ & n & $\%$ & $n$ & $\%$ & \\
\hline $\begin{array}{l}\text { Appropriate } \\
\text { treatment }^{\mathrm{b}}\end{array}$ & 221 & 77 & 144 & 74 & 77 & 82 & NS \\
\hline $\begin{array}{l}\text { At first } \\
\text { prescription }\end{array}$ & 189 & 66 & 119 & 61 & 70 & 74 & 0.03 \\
\hline $\begin{array}{l}\text { At second } \\
\text { prescription }\end{array}$ & 32 & 11 & 25 & 13 & 7 & 7 & NS \\
\hline $\begin{array}{l}\text { Inappropriate } \\
\text { treatment }\end{array}$ & 67 & 23 & 50 & 26 & 17 & 18 & NS \\
\hline
\end{tabular}

Abbreviation: $n$, number; NS, nonsignificant

a Information was missing for 50/338 cases (21/215 in 2013-2015 and 29/123 in 2016)

${ }^{b}$ Appropriate treatment: Doxycycline for 21 days (3)

\section{Reinfections}

Of the 35 individuals who were repeaters (338 cases occurred in 303 individuals), that is, were reinfected more than 90 days after an episode, $10(29 \%)$ had had at least one previous documented episode before 2013, whereas 25 had had their first episode in 2013-2016 (12). Most reinfections (75\%) occurred within two years of first infection (from 108 days to 10.5 years). The LGV repeaters were more likely than those who had had only one episode to be living in Montréal (31/35 [89\%] vs 210/268 [78\%]; 
$p=0.13)$. Compared with individuals who had a single episode, repeaters were also more likely to be HIV-infected

(29/30 [97\%] vs $155 / 193$ [80\%]; $p=0.03)$; to report a past history of syphilis (27/27 [100\%] vs $132 / 173$ [76\%]; $p=0.004) ;$ and to have used recreational drugs during the past 12 months (17/22 [77\%] vs $106 / 194$ [55\%]; $p=0.04)$.

\section{Discussion}

Incidence of LGV, which occurs within a core group of MSM living in an urban setting, has been increasing in Quebec over the last four years. The MSM population is characterized by a significant past history of STBBls, especially HIV, a high number of sexual partners and frequent drug use. Our data show a high prevalence of proctitis as the presenting symptom, with very few classical inguinogenital diseases. The majority of the cases were diagnosed as $L_{2 b}$ genotypes, a variant isolated as far back as the 1980s in San Francisco (13). A number of studies of LGV outbreaks across Europe reported a population of high-risk MSM similar to what we found in the current Quebec outbreak (2). A large percentage of men are HIV and/or hepatitis $C$ positive and very few cases, if any, are detected in heterosexual men or women. Asymptomatic cases have been detected, but the vast majority of cases present with symptoms of rectal infection (14-19).

The LGV rate remains relatively low in comparison with other common STIs including non-LGV C. trachomatis infections. In 2015, among males aged 15-75 years in Quebec, the annual incidence rates of infectious syphilis (17.2/100,000 person-year) and gonococcal infection (69.4/100,000 person-year) were significantly higher than those of LGV (2.6/100,000 person-year) (20). As LGV is thought to be more often symptomatic than syphilis or gonococcal infection, it could be speculated that those who become infected are more likely to seek medical attention and get treatment, restricting transmission. For now, LGV is also confined to a smaller subgroup of MSM, while gonococcal and non-LGV C. trachomatis infections also involve the heterosexual population. However, the incidence prior to 2014 was likely underestimated given the exclusion of asymptomatic patients in previous case definitions. The higher proportion of asymptomatic cases in 2016 can also be partly explained by the systematic genotyping of all positive $C$. trachomatis rectal specimens, which started in June 2016 in Quebec.

The presented clinical manifestations are in line with recent literature reporting proctitis and proctocolitis as the most common presentation $(2,21)$. Although systematic genotyping for LGV is currently performed in Quebec only for rectal specimens, there is some evidence suggesting that extrarectal LGV (pharyngeal and urethral infections) could be a potential contributor to the ongoing outbreak. In 2014, van Rooijen et al. (22) collected pharyngeal swabs from MSM and found that $1 \%$ were C. trachomatis positive; of these, $53 \%$ did not have concomitant anogenital infection. The implication of pharyngeal as well as urethral LGV in transmission of the epidemic strain remains unclear. Rectal infections have been shown to be far more common in various LGV prevalence studies (23-26). It is thus arguable that extrarectal screening would not be a cost-effective measure.

A significant improvement in adequate first prescribed treatment has been noted in 2016, possibly following educational efforts towards physicians $(3,8)$. The province-wide genotyping of positive rectal C. trachomatis specimens implemented in 2016 could have contributed to improvements in case management by shortening diagnostic delays, from a mean of 30 days in 2014 (9), to 12 days in 2016 (data not shown).

A specific subpopulation seems to be at greater risk of reinfection with higher rates of HIV infection, in line with potentially riskier sexual behaviours as shown in other reports $(27,28)$. In an attempt to describe this specific subpopulation, Rönn et al. (12) found repeaters to be more likely to be infected by HIV and HCV, and to have a concomitant gonococcal infection compared with patients with a single episode of LGV. It remains unclear if serosorting, the strategy by which MSM have unprotected sexual encounters with seroconcordant partners, has a role to play in nurturing the present outbreak, as hypothesized for other STls with higher incidence within this specific group $(29,30)$.

The national enhanced LGV surveillance, conducted between 2004 and 2012, received 170 case reports from provincial and territorial health authorities (including 104 confirmed and 66 probable cases) (5). Confirmed cases were reported from Quebec, Ontario, Alberta and British Columbia; probable cases were reported from these provinces as well as one from Nova Scotia (5).

\section{Strengths and limitations}

This study provides recent surveillance data on LGV in Quebec with a high number of cases. Description of risk factors contributes to understanding the current outbreak and its sexual network. Limitations include the descriptive nature and lack of standardization of the questionnaires, both over time and across the different administrative regions, as well as some missing information. Data collecting forms have since been revised and medical teams contacted to allow better standardization. Information regarding HIV follow-up (i.e. treatment, viral load, CD4, etc.) were unfortunately not available.

\section{Conclusion}

The re-emergence of LGV in Quebec involves a core group of MSM with history of STIs, most being HIV-seropositive, with multiple partners and substantial drug use. Sporadic transmission outside of Montréal and relatively frequent reinfections highlight the potential for a further spread; this is of particular significance given the associated morbidity. The transmission among HIV-infected patients is of concern given the implication of unprotected sexual encounters within the LGV-affected population as well as the increased risk of HIV transmission associated with inflammation of rectal mucosa seen in LGV proctitis (1-3). Enhanced surveillance helps monitor and better describe this subgroup in order to tailor public health actions to reduce the risk of LGV transmission. A clinical tool for LGV was released in October 2017 to assist medical teams with LGV screening, diagnosis, treatment, follow-up and partners' medical care (31). The systematic genotyping of rectal specimen positive for $C$. trachomatis proved useful at identifying asymptomatic patients. An analysis of the cost effectiveness of such a strategy would inform future public health actions.

\section{Author's statements}

CAB - Writing - original draft, review and editing, visualization 
SV - Conceptualization, methodology, validation, formal analysis, investigation, writing - review and editing, project administration MF - Conceptualization, methodology, software, validation, formal analysis, data collection and curation, investigation, writing - review and editing, project administration

DM - Methodology, investigation, data collection and curation, writing - review and editing

$\mathrm{CM}$ - Methodology, writing - review and editing

AS - Genotyping by direct sequencing, writing - review and editing

$\mathrm{JL}$ - Resources, writing - review and editing, supervision

CF - Writing - review and editing

$A C L$ - Conceptualization, formal analysis, validation, writing review and editing, visualization, supervision

\section{Conflict of interest}

None.

\section{Acknowledgements}

The authors thank all public health nurses, collaborating physicians, regional public health directorates, the Ministère de la santé et des services sociaux du Québec, Bureau de Vigie sanitaire and the Direction de la lutte contre les ITSS (SLITSS) for the collection and processing of clinical data. We would also like to thank Suzanne Gibbons and Vanessa Zubach at the Viral Exanthemata and STDs laboratory (National Microbiology Laboratory) as well as Martine Morin and Lyne Desautels for the implementation of the multiplex PCR assay at the Laboratoire de santé publique du Québec and laboratory testing of specimens.

\section{Funding}

This epidemiologic study was supported by the provincial public health organizations that participated in data collection and analysis.

\section{References}

1. Ministère de la santé et des services sociaux du Québec. Guide québécois de dépistage de ITSS, Fiche clinique. Lymphogranulomatose vénérienne - MSSS. Québec (QC): MSSS; 2017. http://publications.msss.gouv.qc.ca/msss/ document-000090/

2. Stoner BP, Cohen SE. Lymphogranuloma venereum 2015: clinical presentation, diagnosis, and treatment. Clin Infect Dis 2015 Dec;61 Suppl 8:S865-73. DOI (http://dx.doi. org/10.1093/cid/civ756). PubMed (https://www.ncbi.nlm. nih.gov/entrez/query.fcgi?cmd=Retrieve \&db=PubMed\&li st_uids=26602624\&dopt=Abstract).

3. Public Health Agency of Canada. Canadian Guidelines on Sexually Transmitted Infections. Ottawa (ON): PHAC; 2017. https://www.canada.ca/en/public-health/services/ infectious-diseases/sexual-health-sexually-transmittedinfections/canadian-guidelines/sexually-transmittedinfections.html

4. Kropp RY, Wong T; Canadian LGV Working Group. Emergence of lymphogranuloma venereum in Canada. CMAJ 2005 Jun;172(13):1674-6. DOI (http://dx.doi. org/10.1503/cmaj.050621. PubMed (https://www.ncbi.nlm. nih.gov/entrez/query.fcgi?cmd=Retrieve\&db=PubMed\&li st_uids=15928239\&dopt=Abstract).
5. Public Health Agency of Canada. Section 1: Report on sexually transmitted infections in Canada: 2012 - Chlamydia (Chlamydia trachomatis). Ottawa (ON): PHAC; 2017. https://www.canada.ca/en/public-health/ services/infectious-diseases/surveillance-epidemiolog y-sexually-transmitted-infections-hep-b-c/report-2012/ report-on-sexually-transmitted-infections-canada-2012-5.html

6. Saxon C, Hughes G, Ison C; UK LGV Case-Finding Group. Asymptomatic lymphogranuloma venereum in men who have sex with men, United Kingdom. Emerg Infect Dis 2016 Jan;22(1):112-6. DOI (http://dx.doi.org/10.3201/ EID2201.141867). PubMed (https://www.ncbi.nlm.nih. gov/entrez/query.fcgi?cmd=Retrieve $\& \mathrm{db}=$ PubMed\&lis t_uids=26691688\&dopt=Abstract).

7. de Vrieze NH, de Vries HJ. Lymphogranuloma venereum among men who have sex with men. An epidemiological and clinical review. Expert Rev Anti Infect Ther 2014 Jun;12(6):697-704. DOI (http://dx.doi.org/10.1586/1478 7210.2014.901169). PubMed (https://www.ncbi.nlm.nih. gov/entrez/query.fcgi?cmd=Retrieve\& $\mathrm{db}=$ PubMed\&lis t_uids=24655220\&dopt=Abstract).

8. Comité sur les analyses de laboratoire en lien avec les ITSS (CALI). Lymphogranulomatose vénérienne: avis sur le dépistage, la prise en charge clinique et la surveillance au Québec. Québec (QC): INSPQ; 2016. https://www.inspq. qc.ca/publications/2130

9. Public Health Agency of Canada. Protocol for LGV enhanced surveillance: lymphogranuloma venereum (LGV) in Canada: recommendations for diagnosis and treatment and protocol for national enhanced surveillance. Ottawa (ON): PHAC; 2017. http://www.phac-aspc.gc.ca/publicat/lgv/lgv-rdt2-eng. php

10. Ministère de la Santé et des Services Sociaux du Québec (MSSS). Surveillance des maladies à déclaration obligatoire au Québec - Définitions nosologiques. msss.gouv. qc.ca. 2016. http://publications.msss.gouv.qc.ca/msss/ fichiers/2016/16-268-03W.pdf

11. Chen $\mathrm{CY}, \mathrm{Chi} \mathrm{KH}$, Alexander S, Ison CA, Ballard RC. A real-time quadriplex PCR assay for the diagnosis of rectal lymphogranuloma venereum and non-lymphogranuloma venereum Chlamydia trachomatis infections. Sex Transm Infect 2008 Aug;84(4):273-6. DOI (http://dx.doi.org/10.1136/ sti.2007.029058). PubMed (https://www.ncbi.nlm.nih. gov/entrez/query.fcgi?cmd=Retrieve $\& \mathrm{db}=$ PubMed\&lis t_uids=18283094\&dopt=Abstract).

12. Rönn M, Hughes $G$, White P, Simms I, Ison C, Ward H. Characteristics of LGV repeaters: analysis of LGV surveillance data. Sex Transm Infect 2014 Jun;90(4):275-8. DOI (http:// dx.doi.org/10.1136/sextrans-2013-051386). PubMed (https:// www.ncbi.nlm.nih.gov/entrez/query.fcgi?cmd=Retrieve\&db= PubMed\&list_uids=24431182\&dopt=Abstract).

13. Spaargaren J, Schachter J, Moncada J, de Vries HJ, Fennema HS, Peña AS et al. Slow epidemic of lymphogranuloma venereum L2b strain. Emerg Infect Dis 2005 Nov;11(11):1787-8. DOI (http://dx.doi.org/10.3201/ eid1111.050821). PubMed (https://www.ncbi.nlm.nih. gov/entrez/query.fcgi?cmd=Retrieve $\& \mathrm{db}=$ PubMed\&lis t_uids=16318741\&dopt=Abstract).

14. Haar K, Dudareva-Vizule S, Wisplinghoff $H$, Wisplinghoff $F$, Sailer A, Jansen $K$ et al. Lymphogranuloma venereum in men screened for pharyngeal and rectal infection, Germany. Emerg Infect Dis 2013 Mar;19(3):488-92. DOI (http://dx.doi. org/10.3201/eid1903.121028). PubMed (https://www.ncbi. 
nlm.nih.gov/entrez/query.fcgi?cmd=Retrieve\&db=PubMed\&l ist_uids=23621949\&dopt=Abstract).

15. Spaargaren J, Fennema HS, Morré SA, de Vries HJ, Coutinho RA. New lymphogranuloma venereum Chlamydia trachomatis variant, Amsterdam. Emerg Infect Dis 2005 Jul;11(7):1090-2. PubMed (https://www.ncbi.nlm.nih. gov/entrez/query.fcgi?cmd=Retrieve\&db=PubMed\&lis t_uids $=16022786 \& d o p t=$ Abstract)

16. Rönn MM, Ward $H$. The association between lymphogranuloma venereum and HIV among men who have sex with men: systematic review and meta-analysis. BMC Infect Dis 2011 Mar;11:70. DOI (http://dx.doi. org/10.1186/1471-2334-11-70). PubMed (https://www.ncbi. $\mathrm{nlm}$.nih.gov/entrez/query.fcgi?cmd=Retrieve\&db=PubMed\&l ist_uids=21418569\&dopt=Abstract).

17. de Vrieze NH, van Rooijen M, Schim van der Loeff MF, de Vries HJ. Anorectal and inguinal lymphogranuloma venereum among men who have sex with men in Amsterdam, The Netherlands: trends over time, symptomatology and concurrent infections. Sex Transm Infect 2013 Nov;89(7):548-52. DOI (http://dx.doi.org/10.1136/ sextrans-2012-050915). PubMed (https://www.ncbi.nlm. nih.gov/entrez/query.fcgi?cmd=Retrieve\&db=PubMed\&li st_uids=23427272\&dopt=Abstract).

18. Parra-Sánchez M, García-Rey S, Pueyo Rodríguez I, Viciana Fernández P, Torres Sánchez MJ, Palomares Folía JC. Clinical and epidemiological characterisation of lymphogranuloma venereum in southwest Spain, 2013-2015. Sex Transm Infect 2016 Dec;92(8):629-31. DOI (http://dx.doi.org/10.1136/ sextrans-2015-052453). PubMed (https://www.ncbi.nlm. nih.gov/entrez/query.fcgi?cmd=Retrieve\&db=PubMed\&li st_uids=27288416\&dopt=Abstract).

19. Childs T, Simms I, Alexander S, Eastick K, Hughes G, Field N. Rapid increase in lymphogranuloma venereum in men who have sex with men, United Kingdom, 2003 to September 2015. Euro Surveill 2015;20(48):30076. DOI (http://dx.doi. org/10.2807/1560-7917.ES.2015.20.48.30076). PubMed (https://www.ncbi.nlm.nih.gov/entrez/query.fcgi?cmd=Retrie ve\&db=PubMed\&list_uids=26675210\&dopt=Abstract).

20. Blouin K, Venne S, Lambert G. Portrait des infections transmissibles sexuellement et par le sang (ITSS) au Québec: année 2015 (et projections 2016). Québec (QC): INSPQ; 2017. https://www.inspq.qc.ca/publications/2201

21. de Vrieze NH, Versteeg B, Bruisten SM, van Rooijen MS, van der Helm JJ, de Vries HJ. Low prevalence of urethral lymphogranuloma venereum infections among men who have sex with men: a prospective observational study, sexually transmitted infection clinic in Amsterdam, the Netherlands. Sex Transm Dis 2017 Sep;44(9):547-50. DOI (http://dx.doi.org/10.1097/ OLQ.0000000000000657). PubMed (https://www.ncbi.nlm. nih.gov/entrez/query.fcgi?cmd=Retrieve\&db=PubMed\&li st_uids=28809772\&dopt=Abstract).

22. 22. van Rooijen MS, van der Loeff MF, Morré SA, van Dam AP, Speksnijder AG, de Vries HJ. Spontaneous pharyngeal Chlamydia trachomatis RNA clearance. A cross-sectional study followed by a cohort study of untreated STI clinic patients in Amsterdam, The Netherlands. Sex Transm Infect 2015 May;91(3):157-64. DOI (http://dx.doi.org/10.1136/ sextrans-2014-051633). PubMed (https://www.ncbi.nlm. nih.gov/entrez/query.fcgi?cmd=Retrieve \&db=PubMed\&li st_uids=25237127\&dopt=Abstract).

23. Annan NT, Sullivan AK, Nori A, Naydenova P, Alexander S, McKenna A et al. Rectal chlamydia--a reservoir of undiagnosed infection in men who have sex with men. Sex
Transm Infect 2009 Jun;85(3):176-9. DOI (http://dx.doi. org/10.1136/sti.2008.031773). PubMed (https://www.ncbi. $\mathrm{nlm}$.nih.gov/entrez/query.fcgi?cmd=Retrieve \&db=PubMed\&l ist_uids=19176570\&dopt=Abstract).

24. Rodríguez-Domínguez M, Puerta T, Menéndez B, González-Alba JM, Rodríguez C, Hellín T et al.

Clinical and epidemiological characterization of a lymphogranuloma venereum outbreak in Madrid, Spain: co-circulation of two variants. Clin Microbiol Infect 2014 Mar;20(3):219-25. DOI (http://dx.doi.org/10.1111/14690691.12256). PubMed (https://www.ncbi.nlm.nih.gov/ entrez/query.fcgi?cmd=Retrieve\&db=PubMed\&list_ uids $=23730727 \&$ dopt=Abstract).

25. Ward H, Alexander S, Carder C, Dean G, French P, Ivens $D$ et al. The prevalence of lymphogranuloma venereum infection in men who have sex with men: results of a multicentre case finding study. Sex Transm Infect 2009 Jun;85(3):173-5. DOI (http://dx.doi.org/10.1136/ sti.2008.035311). PubMed (https://www.ncbi.nlm.nih. gov/entrez/query.fcgi?cmd=Retrieve\& $\mathrm{db}=$ PubMed\&lis t_uids=19221105\&dopt=Abstract).

26. de Vrieze NH, van Rooijen M, Speksnijder AG, de Vries HJ. Urethral lymphogranuloma venereum infections in men with anorectal lymphogranuloma venereum and their partners: the missing link in the current epidemic? Sex Transm Dis 2013 Aug;40(8):607-8. DOl (http://dx.doi.org/10.1097/01. OLQ.0000431359.26583.13). PubMed (https://www.ncbi. $\mathrm{nlm}$.nih.gov/entrez/query.fcgi?cmd=Retrieve\&db=PubMed\&l ist_uids=23859905\&dopt=Abstract).

27. Macdonald N, Sullivan AK, French P, White JA, Dean G, Smith A et al. Risk factors for rectal lymphogranuloma venereum in gay men: results of a multicentre case-control study in the U.K. Sex Transm Infect 2014 Jun;90(4):262-8. DOI (http://dx.doi.org/10.1136/ sextrans-2013-051404). PubMed (https://www.ncbi.nlm. nih.gov/entrez/query.fcgi?cmd=Retrieve $\& d b=$ PubMed $\&$ li st_uids=24493859\&dopt=Abstract).

28. de Vries HJ, van der Bij AK, Fennema JS, Smit C, de Wolf $\mathrm{F}$, Prins $\mathrm{M}$ et al. Lymphogranuloma venereum proctitis in men who have sex with men is associated with anal enema use and high-risk behavior. Sex Transm Dis 2008 Feb;35(2):203-8. DOI (http://dx.doi.org/10.1097/ OLQ.0b013e31815abb08). PubMed (https://www.ncbi.nlm. nih.gov/entrez/query.fcgi?cmd=Retrieve $\& d b=$ PubMed $\&$ li st_uids=18091565\&dopt=Abstract).

29. Marcus U, Schmidt AJ, Hamouda O. HIV serosorting among HIV-positive men who have sex with men is associated with increased self-reported incidence of bacterial sexually transmissible infections. Sex Health 2011 Jun;8(2):184-93. DOI (http://dx.doi.org/10.1071/SH10053). PubMed (https:// www.ncbi.nlm.nih.gov/entrez/query.fcgi?cmd=Retrieve\&db= PubMed\&list_uids=21592432\&dopt=Abstract).

30. Jin F, Prestage GP, Templeton DJ, Poynten IM, Donovan B, Zablotska I et al. The impact of HIV seroadaptive behaviors on sexually transmissible infections in HIV-negative homosexual men in Sydney, Australia. Sex Transm Dis 2012 Mar;39(3):191-4. DOI (http://dx.doi.org/10.1097/ OLQ.0b013e3182401a2f). PubMed (https://www.ncbi.nlm. nih.gov/entrez/query.fcgi?cmd=Retrieve $\& d b=$ PubMed $\&$ li st_uids=22337105\&dopt=Abstract).

31. Ministère de la santé et des services sociaux du Québec (MSSS). Recrudescence de la lymphogranulomatose vénérienne au Québec: détection et traitement. Québec (QC): Gouvernement du Québec; 2017. http://publications. msss.gouv.qc.ca/msss/document-001956/ 